\title{
Embryonic development time of the freshwater mysid Limnomysis benedeni Czerniavsky as a function of water temperature
}

\author{
Almut J. Hanselmann • René Gergs • \\ Karl-Otto Rothhaupt
}

\begin{abstract}
The numbers of alien species in freshwater systems and their detrimental impacts on the stability of ecosystems and global species diversity are increasing. To predict and assess such impacts, a thorough knowledge of the autecology and life cycle of the alien species is required. Limnomysis benedeni is common and one of the most invasive mysids in Europe. Here we show a clear dependency of the development time of the brood of $L$. benedeni on water temperature. In laboratory experiments (one in spring 2008 and two in 2009 , in spring and summer) under controlled conditions, we determined embryonic development times and the probability of survival of the females and juveniles at water temperatures ranging from 4 to $25^{\circ} \mathrm{C}$. At 6.5 and $25^{\circ} \mathrm{C}$, the probability of survival of both the females and the larvae was lower than at 10, 15 , or $20^{\circ} \mathrm{C}$. Since the development time is one of the key characteristics of the life cycle and is therefore
\end{abstract}

Handling Editor: Piet Spaak.

\footnotetext{
A. J. Hanselmann (ه) - K. O. Rothhaupt

Limnological Institute, University of Konstanz,

78457 Constance, Germany

e mail: almut.hanselmann@gmx.de

R. Gergs

Institute for Environmental Sciences, University

of Koblenz Landau, 76829 Landau, Germany
}

necessary to calculate, for example, birth and mortality rates, we determined an equation for the development time as a function of the water temperature. This information will be useful to understand the distribution potential of this invasive species.

Keywords Population dynamics $\cdot$ Larvae . Climate change $\cdot$ Marsupium

\section{Introduction}

With increasing numbers of alien species in freshwater systems such as the River Rhine (Leuven et al. 2009), their detrimental impact on both the stability of ecosystems and the global diversity of species is also increasing (Sala et al. 2000). To be able to predict the impacts of alien species on resident species and communities, detailed information on their autecology and life cycle is required. The expansion of an invasive species is often enabled or limited by the temperature, especially with a possible influence of climate change (Vermonden et al. 2010).

Many common alien species in Central Europe are freshwater Crustacea, including Mysida (Leuven et al. 2009). In contrast to marine mysids, many life-cycle properties of freshwater mysids, e.g., development times of the brood, growth rates, and mortality rates, are still unknown. This information is important to determine the influence of an alien species on the 
invaded ecosystem and to understand the distribution potential of an invasive species. The generation time is related to the duration of the reproduction period, the age at maturity, the number of broods, the brood size, and the body length of the adults (Ishikawa and Oshima 1951; Murano 1964; Davis 1966; Mauchline 1973; Wittmann 1984).

Limnomysis benedeni Czerniavsky, 1882, is one of the most invasive mysids in Europe; it is a common invasive species, originates in the brackish estuaries of the Black Sea and Caspian Sea, and has spread nearly throughout Eastern and Central Europe since the early twentieth century (Bij De Vaate et al. 2002; Wittmann and Ariani 2008; Audzijonyte et al. 2009). The mysid was found for the first time in Lake Constance in 2006 (Fritz et al. 2006). The species has been characterized as a necto-benthic (Porter et al. 2008), phyto-lithophilic (Dediu 1966), suspensions feeder (Gergs et al. 2008; Aßmann et al. 2009). In winter, in Lake Constance, the population does not reproduce, and the adults invest in body growth. In spring and summer, the species reproduces continuously. In spring, the large overwintering females produce large egg clutches. In summer, adults reach maturity at a size smaller than that in winter and produce smaller clutches (Hanselmann et al. 2011).

In general, the life cycle of a mysid is strongly correlated with the climate regime in its environment (Wittmann 1984). Within the order Mysida, the lifehistory trades, including, e.g., development time, generation time, and clutch size, vary widely. In temperate zones, as in Central Europe, with seasonal fluctuating water temperature, species of the family Mysidae, including L. benedeni, normally reproduce only during the summer (Wittmann 1984). The common attribute of the superorder Peracarida, to which the family belongs, is that brood development takes place in a brood pouch of the females, the marsupium, which is built by the sternites of the thorax and a pair of oostegites (Westheide and Rieger 1996). Larval development occurs inside the marsupium. Eggs are fertilized by the male directly after the female lays them in the marsupium and embryonic development and all larval stages except the last larval molt take place inside the marsupium. Just before the last larval molt, the female sets the larvae free and the last larvae molt takes place directly after the larvae leave the marsupium. This development is similar for all mysid species (Mauchline 1973; Wittmann 1984). The adult females protect their brood, provide it with oxygen by pumping movements of the oostegites, and are to a small extent responsible for the spatial arrangement of the larvae in the brood pouch (Wittmann 1978; Mauchline 1980). Each developing larva feeds on yolk invested by the mother in its egg (Morgan 1980), but the diameter of the eggs, as a proxy of the yolk mass, plays a subordinate role for the development time of other mysid species in comparison with the water temperature (Wittmann 1981b).

We determined to what extent mysid embryonic development time depends on water temperature in laboratory experiments under controlled conditions at different water temperatures. Furthermore, we determined the probability of survival of the females and juveniles.

\section{Methods}

Experimental set-ups

To measure the relationship between temperature and the development time of the brood in the marsupium, we chose a temperature range from 4 to $25^{\circ} \mathrm{C}$. We ran three experiments, one in spring 2008 (run I, starting on April 24, at 4,10,15,20, and $25^{\circ} \mathrm{C}$ ) and two in 2009, in spring (run II, starting on April 30, at 6.5, 10, 15 , and $20^{\circ} \mathrm{C}$ ) and summer (run III, starting on July 30 , at 15 and $20^{\circ} \mathrm{C}$ ). Run III was carried out to see whether the eggs from the smaller summer clutches have development times comparable to the eggs from the larger spring clutches. Three climate chambers and two climate cabinets (plant growth chamber KBW 720, Binder GmbH, Tuttlingen) were used to provide a stable water temperature; the overall tolerance was $\pm 0.3^{\circ} \mathrm{C}$. In all experiments, the same light conditions with a diurnal light rhythm of $12 \mathrm{~h} 12 \mathrm{~h}$ (day night) and the same experimental setup were used. Day length in the field was about $14 \mathrm{~h}$ in April and $15 \mathrm{~h}$ in July.

For each temperature, 50 brood-carrying females (except in run III, which had 35 at $15^{\circ} \mathrm{C}$ and 40 at $20^{\circ} \mathrm{C}$ because fewer breeding females were available) were kept individually in 11 glass jars with $750 \mathrm{ml}$ filtered $(30 \mu \mathrm{m})$ and slightly aerated lake water. We used the green alga Scenedesmus obliquus (Turpin) (SAG 276-3a, Göttingen, Germany) as food, which was added ad libitum (4 $\mathrm{ml}$ suspension, $\sim 1 \mathrm{mg} / \mathrm{l}$ carbon) 
twice a week. During earlier experiments, we measured that this was more than the females were able to consume. Once a week, the glasses were cleaned carefully with a soft brush and the water was replaced.

The gravid females were freshly caught in the eastern part of Lake Constance in Austria near the confluence of the Rhine River at $\sim 0.5 \mathrm{~m}$ depth. For determining the clutch size and categorizing the stages of the larvae in the marsupium at the beginning of each set of experiments, a sample of the population was caught via kick-sampling and directly fixed with $96 \%$ ethanol. The females caught for the experiments were adapted overnight to the respective temperature and placed into the glass jars the next morning. Because $L$. benedeni neonates are released during the night (Mauchline 1980), the water in the glass jars was checked for neonates once each morning; hatched juveniles and their mother were directly fixed in $96 \%$ ethanol and counted. If a female died, it was not removed unless the decomposition process inhibited larval development. Inhibiting conditions occurred when the decay of the dead mother started to pollute the water (visible pollution or smelling water).

\section{Calculations and statistics}

For the development time at each temperature $\left(D_{\mathrm{T}}\right)$, the number of remaining egg-carrying females was plotted against time. The $\mathrm{x}$-axis intercept of the linear regression $(y=0)$ is the calculated development time for the respective temperature. These $D_{\mathrm{T}}$ values were then plotted against the temperature to obtain the relationship between development time and temperature. The probability of survival at each temperature was calculated for females and larvae. For larvae, the mean brood size of hatched larvae of each replicate was compared to the mean brood size at the beginning, which was determined in the field, as described above; the field brood sizes of the runs differed. The optimal temperatures were calculated from the first derivation of the nonlinear regression that described the correlation.

A linear-regression model was calculated for each temperature in each experiment, and a nonlinearregression model was calculated for the relationship between development time and temperature and for the probabilities of survival ( $\mathrm{R}$ Development Core Team 2008).

\section{Results}

Development time

At all temperatures except $4^{\circ} \mathrm{C}$, juvenile mysids hatched, and we could determine the development times of L. benedeni in the marsupium (Fig. 1). For these resulting development times, the linear regression of time versus the number of remaining females was significant (Table 1). When the measured development times were plotted against the temperature, a significant negative exponential curve was obtained $\left(y=122.549 \times \mathrm{e}^{-0.127}, P<0.001\right.$; Fig. 2; Table 2). The validity of this equation ends below $6.5^{\circ} \mathrm{C}$ because at the next lower tested temperature at $4^{\circ} \mathrm{C}$ in run $\mathrm{I}$, no juvenile $L$. benedeni were found, all females died within 60 days, and the experiment was stopped after 80 days. For temperatures above $25^{\circ} \mathrm{C}$, the equation is not tested. In the summer experiments (run III), the hatching of the juveniles started immediately, whereas in the spring experiments (run I and II), the first juveniles were found after several days (Fig. 1).

\section{Clutch size and probability of survival}

The brood size of the mysids caught in the field at the beginning of each experiment was $20 \pm 4.5$ larvae/ female in run I, $18.2 \pm 5.1$ larvae/female in run II, and $6.2 \pm 2.2$ larvae/female in run III. The mean brood sizes (hatched juveniles) at all temperatures (Table 1) decreased as the development time increased. The probability of survival of both the mother $\left(R^{2}=0.62\right)$ and the larvae $\left(R^{2}=0.83\right)$ at each temperature tested is described with a nonlinear-regression curve (Fig. 3; Table 2). At 6.5 and $25^{\circ} \mathrm{C}$, the probability of survival of the mothers (Fig. 3a) and of the larvae (Fig. 3b) was lower than at 10,15 , and $20^{\circ} \mathrm{C}$. The optimal and maximum temperature for survival of both the mothers and the larvae was $15.9^{\circ} \mathrm{C}$ (Table 2).

\section{Discussion}

Our experiments, which provide the first determination of the embryonic development time of a freshwater mysid, revealed a clear dependency of the development time of the brood of $L$. benedeni on the water temperature. The tested temperatures between 4 
Fig. 1 Breeding females of $L$. benedeni remaining after checking the glass jars for juveniles every morning (see "Methods") during the experiments. Lettering indicates the temperature $\left(6.525^{\circ} \mathrm{C}\right.$ ) and the time (run I III) of each experiment. Please pay attention to the different $x$ axis scaling. Data represented by black dots were used in the linear regression
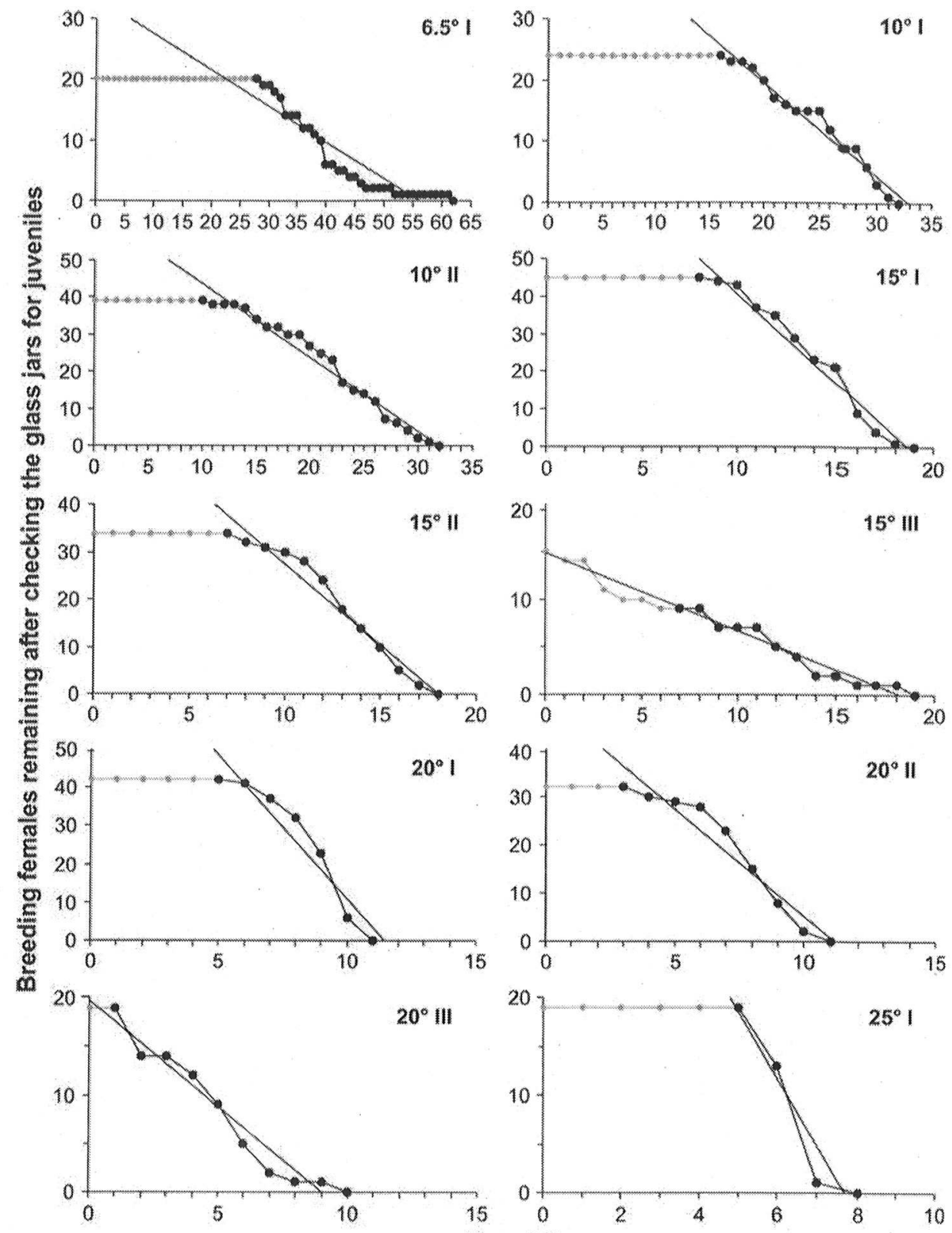

Time [d]

and $25^{\circ} \mathrm{C}$ represent the range observed in the littoral of Lake Constance (Stich and Brinker 2010; Hanselmann et al. 2011) and in most lakes in temperate zones in which L. benedeni is found (Wittmann and Ariani 2008; Audzijonyte et al. 2009).

At $4^{\circ} \mathrm{C}$, eggs did not develop. The coldest temperature at which the larvae developed to juveniles was at $6.5^{\circ} \mathrm{C}$, which is close to the temperature measured in the field at which the first breeding females were found in spring $2008\left(6.6^{\circ} \mathrm{C}\right.$, Hanselmann et al. 2011). Because of the negative exponential relationship, fluctuations at lower temperatures cause much higher changes in the development time than fluctuations at higher temperatures. Therefore, the speed at which water warms in spring and the higher water temperatures in winter that will probably be caused by climate warming (Straile et al. 2003) should have a greater influence on population growth, abundance, and the length of the reproductive period of the mysids than fluctuations in the maximum summer temperatures. The summer temperatures, on the other hand, influence the distribution and survival of $L$. benedeni. 

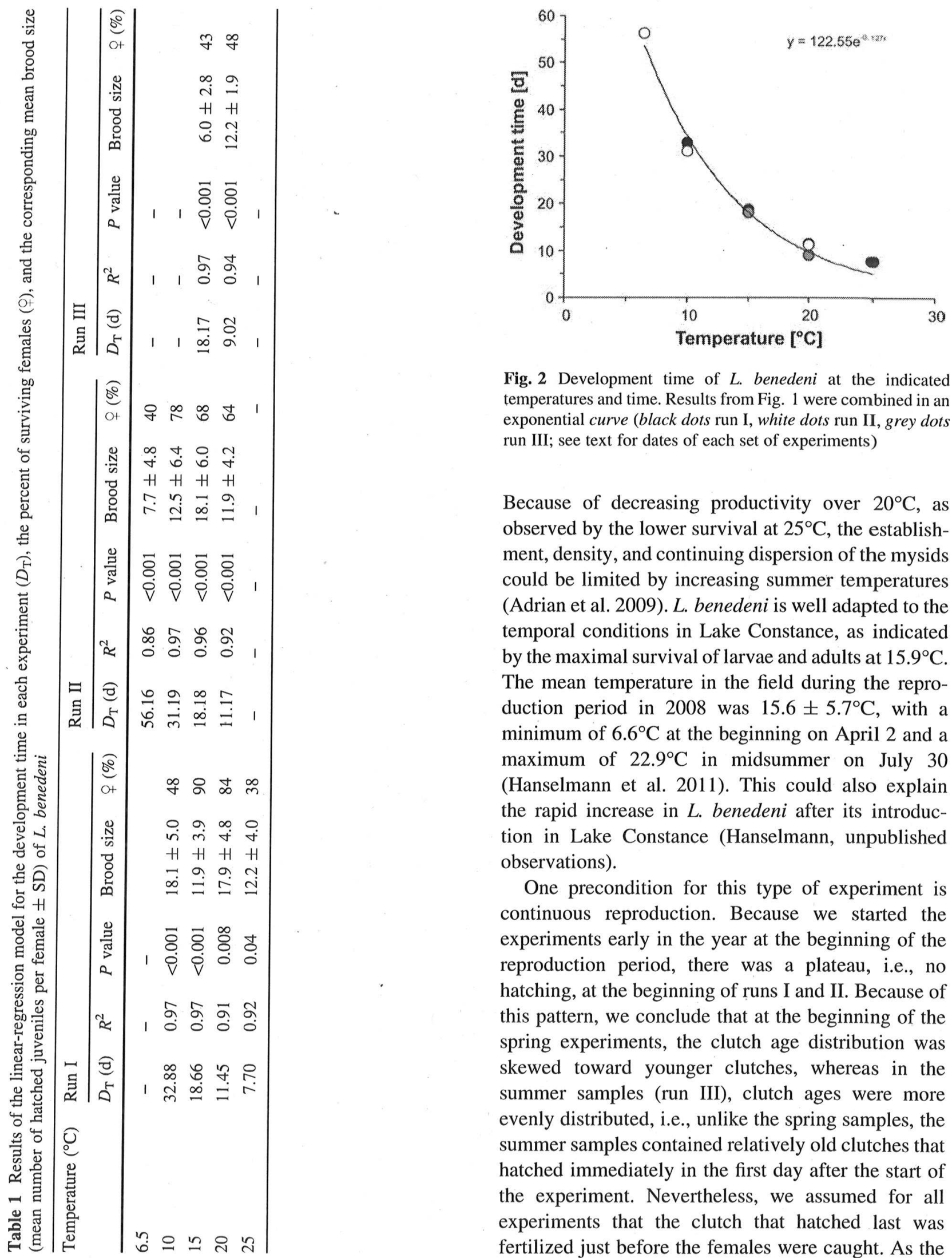

Fig. 2 Development time of $L$. benedeni at the indicated temperatures and time. Results from Fig. 1 were combined in an exponential curve (black dots run I, white dots run II, grey dots run III; see text for dates of each set of experiments)

Because of decreasing productivity over $20^{\circ} \mathrm{C}$, as observed by the lower survival at $25^{\circ} \mathrm{C}$, the establishment, density, and continuing dispersion of the mysids could be limited by increasing summer temperatures (Adrian et al. 2009). L. benedeni is well adapted to the temporal conditions in Lake Constance, as indicated by the maximal survival of larvae and adults at $15.9^{\circ} \mathrm{C}$. The mean temperature in the field during the reproduction period in 2008 was $15.6 \pm 5.7^{\circ} \mathrm{C}$, with a minimum of $6.6^{\circ} \mathrm{C}$ at the beginning on April 2 and a maximum of $22.9^{\circ} \mathrm{C}$ in midsummer on July 30 (Hanselmann et al. 2011). This could also explain the rapid increase in $L$. benedeni after its introduction in Lake Constance (Hanselmann, unpublished observations).

One precondition for this type of experiment is continuous reproduction. Because we started the experiments early in the year at the beginning of the reproduction period, there was a plateau, i.e., no hatching, at the beginning of runs I and II. Because of this pattern, we conclude that at the beginning of the spring experiments, the clutch age distribution was skewed toward younger clutches, whereas in the summer samples (run III), clutch ages were more evenly distributed, i.e., unlike the spring samples, the summer samples contained relatively old clutches that hatched immediately in the first day after the start of the experiment. Nevertheless, we assumed for all experiments that the clutch that hatched last was fertilized just before the females were caught. As the 
Table 2 Results of the nonlinear regression model for the probability of survival of females and larvae of $L$. benedeni, with calculations of the optimal temperature (maximum) and of the temperature dependent development time

\begin{tabular}{|c|c|c|c|c|c|c|c|}
\hline & Parameter & $\begin{array}{l}\text { Estimated } \\
\text { value }\end{array}$ & SE & $T$ value & $P$ value & $R^{2}$ & $\begin{array}{l}\text { Maximum } \\
\left({ }^{\circ} \mathrm{C}\right)\end{array}$ \\
\hline \multicolumn{5}{|c|}{ Optimal temperature } & Formula & \multicolumn{2}{|c|}{$a x^{2}+b x+d$} \\
\hline \multirow[t]{3}{*}{ Females } & $a$ & 0.443 & 0.140 & 3.159 & 0.013 & \multirow[t]{3}{*}{0.6196} & \multirow[t]{3}{*}{15.94} \\
\hline & $b$ & 14.108 & 4.079 & 3.459 & 0.009 & & \\
\hline & $d$ & 402.950 & 26.823 & 1.502 & 0.171 & & \\
\hline \multirow[t]{3}{*}{ Juveniles } & $a$ & 0.556 & 0.103 & 5.421 & $<0.001$ & \multirow[t]{3}{*}{0.8247} & \multirow[t]{3}{*}{15.87} \\
\hline & $b$ & 17.635 & 2.985 & 5.909 & $<0.001$ & & \\
\hline & $d$ & 51.841 & 19.627 & 2.641 & 0.030 & & \\
\hline \multicolumn{6}{|c|}{ Temperature dependent development time } & \multirow{3}{*}{$\begin{array}{l}\text { Formula } f \\
0.985\end{array}$} & \multirow[t]{3}{*}{$a \times \mathrm{e}^{b x}$} \\
\hline & $a$ & 122.549 & 8.27 & 14.81 & $<0.001$ & & \\
\hline & $b$ & 0.127 & 0.006 & 19.58 & $<0.001$ & & \\
\hline
\end{tabular}
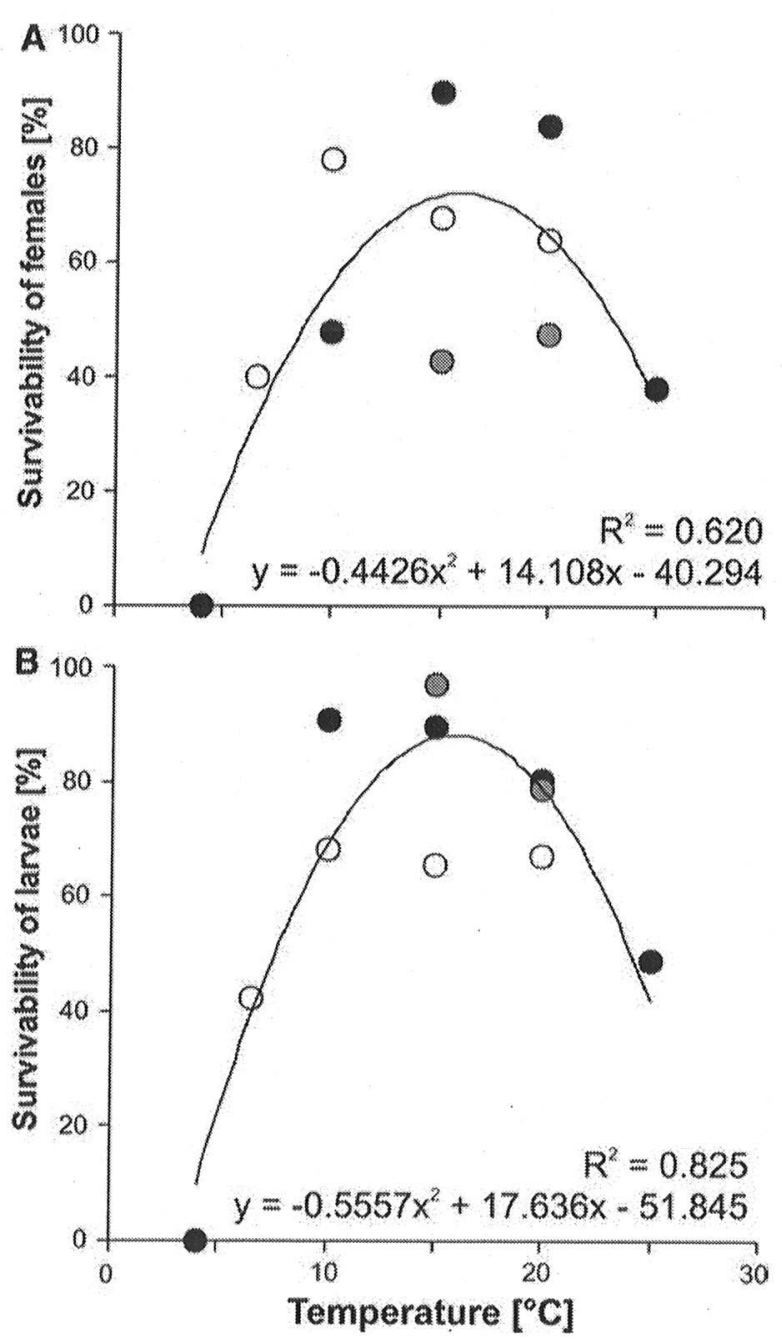

Fig. 3 Probability of survival of females $\mathbf{a}$ and larvae $\mathbf{b}$ at the temperatures indicated in three experiments (filled circle run I, open circle run II, filled gray circle run III; see text for dates of each set of experiments) decline of breeding females, respectively the hatching of the juveniles during our experiments, is well described by a straight line (Fig. 1), we concluded that the reproduction was continuous and that our sampling size of 50 females was large enough to include a newly breeding female.

The deviation at $20^{\circ} \mathrm{C}$ in run III (summer) from runs I and II (spring) could possibly be caused by the lower number of females. At the end of July, when we started the experiment, only few breeding females were found. At this time, the abundance of the population of L. benedeni in Lake Constance was lower probably because of size-selective predation by juvenile perch on the large-length classes of the mysid (Hanselmann et al. 2011). Because of reduced adults available in the field, it could be that in our sampling no female was included with a clutch fertilized the night before. So the last clutch could be fertilized some days before catching, which would lead to an underestimation of the development time. The described equation (Fig. 2) could therefore, underestimate but never overestimate the egg development time.

Compared to previous methods, such as storing the eggs out of the marsupium in petri dishes (Manton 1928; Modlin 1979; Wittmann 1981a; Johnston et al. 1997; Fockedey et al. 2006; Ghekiere et al. 2007), our experimental method avoided the stress of removing the larvae from the marsupium and handling them during water exchange. We reduced negative effects resulting from possible oxygen deficits by allowing the female to care for the brood. Therefore, we introduced a facile method for working in vivo with the larvae of $L$. benedeni, which can be used to answer ecotoxicological questions (Verslycke et al. 2007). 
In our future studies on population processes of $L$. benedeni, we intend to quantify the changes in population size over time, and finally develop a model based on the mysids characteristics (inter alia rates in relation to environmental factors such as the embryonic development time, growth rates, and birth rates) to calculate and predict population dynamics and mortality rates.

Acknowledgments We thank Bettina Hodapp and Philipp Menzel for their help in the laboratory and Karen A. Brune for editing the English language.

\section{References}

Adrian R, O'Reilly CM, Zagarese H, Baines SB, Hessen DO, Keller W, Livingstone DM, Sommaruga R, Straile D, Van Donk E, Weyhenmeyer GA, Winder M (2009) Lakes as sentinels of climate change. Limnolog Oceanogr 54:2283 2297

Aßmann C, Von Elert E, Gergs R (2009) Effects of leaf litter and its fungal colonization on the diet of Limnomysis benedeni (Crustacea: Mysida). Hydrobiologia 636:439 447

Audzijonyte A, Wittmann KJ, Ovcarenko I, Väinölä R (2009) Invasion phylogeography of the Ponto Caspian crustacean Limnomysis benedeni dispersing across Europe. Divers Distrib 15:346 355

Bij de Vaate A, Jazdzewski K, Ketelaars HAM, Gollasch S, Van der Velde G (2002) Geographical patterns in range exten sion of Ponto Caspian macroinvertebrate species in Eur ope. Can J Fish Aquat Sci 59:1159 1174

Davis CC (1966) A study of the hatching process in aquatic invertebrates, XXII. Multiple membrane shedding in My sidium columbiae (Zimmer) (Crustacea: Mysidacea). Bull Mar Sci 16:124 131

Dediu II (1966) Répartition et caractéristique écologique des Mysides des bassins des rivièrs Dniestr et Pruth. Rev Roum Biol/Ser Zool 11:233 239

Fockedey N, Ghekiere A, Bruwiere S, Janssen CR, Vinex M (2006) Effect of salinity and temperature on the intra marsupial development of the brackish water mysid Neomysis integer (Crustacea: Mysidacea). Mar Biol 148: 13391356

Fritz B, Nisch A, Wittkugel C, Mörtl M (2006) First record of Limnomysis benedeni Czerniavsky in Lake Constance (Crustacea: Mysidacea). Lauterbornia 58:157 160

Gergs R, Hanselmann AJ, Eisele I, Rothhaupt KO (2008) Aut ecology of Limnomysis benedeni Czerniavsky, 1882 (Crustacea: Mysida) in Lake Constance, southwestern Germany. Limnologica 38:139 146

Ghekiere A, Fockedey N, Verslycke T, Vincx M, Janssen CR (2007) Marsupial development in the mysid Neomysis integer (Crustacea: Mysidacea) to evaluate the effects of endocrine disrupting chemicals. Ecotox Environ Saf $66: 9 \quad 15$

Hanselmann AJ, Gergs R, Rothhaupt K O (2011) Seasonal shifts in the life cycle of the ponto caspian invader
Limnomysis benedeni (Crustacea: Mysida): a physiological adaptation. Hydrobiologia 673:193 204

Ishikawa M, Oshima Y (1951) On the life history of a mysid crustacean Neomysis japonica Nakazawa. Bull Jpn Soc Sci Fish 16:461 472

Johnston NM, Ritz DA, Fenton GE (1997) Larval development in the Tasmanian mysids Anisomysis mixta australis, Tenagomysis tasmaniae and Paramesopodopsis rufa (Crustacea: Mysidacea). Mar Biol 130:93 99

Leuven RSEW, van der Velde G, Baijens I, Snijders J, van der Zwart C, Lenders HJR, bij de Vaate A (2009) The river Rhine: a global highway for dispersal of aquatic invasive species. Biol Invasions 11:1989 2008

Manton SM (1928) On the embryology of a mysid Crustacean, Hemimysis Lamornae. Philos Trans R Soc Lond B Biol Sci 216:363 463

Mauchline J (1973) The broods of British Mysidacea (Crusta cea). J Biol Assoc UK 53:801 817

Mauchline J (1980) The biology of mysids and euphausiids. Adv Mar Biol 18:1 681

Modlin RF (1979) Development of Mysis stenolepis (Crustacea: Mysidacea). Am Midl Nat 101:250 254

Morgan MD (1980) Life history characteristics of two intro duced populations of Mysis relicta. Ecology 61:551 561

Murano M (1964) Fisheries biology of a marine relict mysid Neomyis intermedia Czerniavsky. IV. Life cycle, with special reference to growth. Aquiculture (Jpn) 12:109 117

Porter ML, Meland K, Price W (2008) Global diversity of mysids (Crustacea Mysida) in freshwater. Hydrobiologia 595:213 218

R Development Core Team (2008) R: a language and environ ment for statistical computing. R Foundation for Statistical Computing, Vienna

Sala OE, Chapin FS III, Armesto JJ, Berlow E, Bloomfield J, Dirzo R, Huber Sanwald E, Huenneke LF, Jackson RB, Kinzig A, Leemanns R, Lodge DM, Mooney HA, Oester held M, Poff NL, Sykes MT, Walker BH, Walker M, Wall DH (2000) Global biodiversity scenarios for the year 2100 . Science 287:1770 1774

Stich H B, Brinker A (2010) Oligotrophication outweighs effects of global warming in a large, deep, stratified lake ecosystem. Glob Chang Biol 16:877 888

Straile D, Jöhnk K, Rossknecht H (2003) Complex effects of winter warming on the physicochemical characteristics of a deep lake. Limnol Oceanogr 48:1432 1438

Vermonden K, Leuven RSEW, Van der Velde G (2010) Envi ronmental factors determining invasibility of urban waters for exotic macroinvertebrates. Divers Distrib 16:1009 1021

Verslycke T, Ghekiere A, Raimondo S, Janssen C (2007) Mysid crustaceans as standard models for the screening and test ing of endocrine disrupting chemicals. Ecotoxicology 16:205 219

Westheide W, Rieger R (1996) Spezielle Zoologie, Erster Teil: Einzeller und Wirbelose Tiere. Gustav Fischer Verlag, Stuttgart

Wittmann KJ (1978) Adoption, replacement, and identification of young in marine Mysidacea (Crustacea). J Exp Mar Biol Ecol 32:259 274

Wittmann KJ (1981a) Comparative biology and morphology of marsupial development in Leptomysis and other 
mediterranean Mysidacea (Crustacea). J Exp Mar Biol Ecol 52:243 270

Wittmann KJ (1981b) On the breeding biology and physiology of marsupial development in mediterranean Leptomysis (Mysidacea: Crustacea) with special reference to the effects of temperature and egg size. J Exp Mar Biol Ecol 53:261 279
Wittmann KJ (1984) Ecophysiology of marsupial development and reproduction in Mysidacea (Crustacea). Oceanogr Mar Biol Annu Rev 22:393 428

Wittmann KJ, Ariani AP (2008) Reappraisal and range exten sion of non indigenous Mysidae (Crustacea, Mysida) in continental and coastal waters of eastern France. Biol Invasions 11:401 407 